\title{
Contained rupture of an infected abdominal aneurysm eroding into the L4 vertebra in a patient after aorto-femoral reconstruction
}

\author{
Róbert Novotnýa, Libor Janoušek ${ }^{a, b}$, Jaroslav Chlupáč ${ }^{a, b}$, Karel Sutoris ${ }^{a}$, \\ Michal Kudlaa, Jiří Froněk ${ }^{a, b, c}$
}

a Transplant Surgery Department, Institute for Clinical and Experimental Medicine, Prague

${ }^{b}$ First Faculty of Medicine, Charles University, Prague

' Second Faculty of Medicine, Charles University, Prague

\section{ARTICLE INFO}

Article history:

Submitted: 29. 7. 2019

Revised: 20. 8. 2019

Accepted: 5. 12. 2019

Available online: 7. 7. 2020

\section{Kličová slova:}

Břišní aneurysma

Eroze

Infekce

Obratle

Ohraničená ruptura

\section{SOUHRN}

Úvod: Chronická ohraničená ruptura břišního aneurysmatu (AAA) erodující do obratlů je relativně neobvyklá. Jedním z projevů kromě pulsující břišní rezistence může být nespecifická bolest v dolní části zad. Kazuistika: Sedmdesátiletý pacient, muž po pravém aortofemorálním protetickém bypassu (RAFB) před jedenácti lety, byl předán do našeho centra s nespecifickou bolestí dolní části zad, která trvala posledních 12 hodin. Výpočetní tomografická angiografie (CTA) odhalila prasklé AAA $57 \times 63 \mathrm{~mm}$ erodující do obratle L4. U pacienta byla naplánována chirurgická intervence. Mikrobiologické vyšetření kultury z AAA následně prokázalo infekci Staphylococcus hominis. Po zákroku byla u pacienta zahájena tř́týdenní antibiotická terapie linezolidem.

Výsledky: V současné době máme tříměsíční sledování u pacienta bez známek infekce v protetické náhradě infrarenální aorty na základě ultrazvuku.

Závěr: Bolest dolní části zad je častá lékařská diagnóza. Jejím důvodem však nemusí být vždy primární onemocnění páteře. Chronické prasklé AAA s erozí vertebrálních obratlů je neobvyklým projevem prasklého AAA.

(c) 2020, ČKS.

\section{ABSTRACT}

Introduction: Chronic contained rupture of the abdominal aneurysm (AAA) eroding into the vertebrae is relatively uncommon. One of its manifestations besides pulsatile abdominal mass can be unspecific low back pain.

Case presentation: A 70-year-old male patient after right aorto-femoral prosthetic bypass (RAFB) eleven years ago was referred to our center with non-specific lower back pain lasting for the past 12 hours. Computed tomography angiography (CTA) revealed contained ruptured $57 \times 63 \mathrm{~mm}$ AAA protruded into the $\mathrm{L} 4$ vertebra. The patient was scheduled for an open repair through a midline laparotomy. Microbiological examination from the AAA sack revealed positive culture of Staphylococcus hominis. After the procedure a three-week_antibiotic treatment with Linezolid was started in the patient.

Keywords:

Abdominal aneurysm

Contained rupture

Erosion

Results: Currently we have three-month follow up of the patient with no signs of infection in the aortic polyester graft based on ultrasonography.

Conclusion: Low back pain is a widespread medical diagnosis. However, its reason may not always be a primary spine disease. Chronic contained ruptured AAA with vertebral body erosion is an uncommon manifestation of a ruptured AAA.

Address: MUDr. Libor Janoušek, Ph.D., FEBS, Transplant Surgery Department, Institute for Clinical and Experimental Medicine, Vídeňská 1958/9, 14021 Prague 4, e-mail: lija@ikem.cz 


\section{Introduction}

The first chronic contained ruptured abdominal aortic aneurysm (AAA) eroding into the vertebrae was described by Choplin at el. in $1982 .{ }^{1}$ One of its manifestations besides pulsatile abdominal mass can be unspecific lower back pain. However, lower back pain is often suggested as the most frequent type of pain. Up to $40 \%$ of general population adults are diagnosed with chronic back pain at some point. ${ }^{2}$ Other diagnoses such as primary bone tumours, rheumatoid arthritis, osteomalacia, infectious processes like vertebral tuberculosis, vertebral pyogenic spondylodiscitis psoas abscess can also mimic the same manifestation as a chronic contained ruptured AAA. ${ }^{2}$ Thus, making the diagnosis difficult and sometimes not thought of.

\section{Case report}

A 70-year-old male patient after right aorto-femoral prosthetic bypass (RAFB) eleven years ago was referred to our center with non-specific lower back pain lasting for the past 12 hours. Patient's medical history; RAFB 2008, type 2 diabetes mellitus on single therapy with vildagliptin, lung embolism in 2008, currently on warfarin. Patient's blood work showed on admission a slightly elevated inflammatory markers (CRP: $\left.25 \mathrm{mg} / \mathrm{L}, \mathrm{WBC}: 12.5 \times 10^{\%} / \mathrm{l}\right)$ and pathological coagulation due to the use of warfarin (INR: 2.14, PT: 29\%). Computed tomography angiography (CTA) revealed contained ruptured $57 \times 63 \mathrm{~mm}$ AAA protruded into the L4 vertebrae (Fig. 1). The proximal anastomosis of the RAFB originated on the border of AAA and undilated aorta. Once the coagulation was corrected to an acceptable level, the patient was scheduled for an open repair of the AAA.

Under general anesthesia through a midline-laparotomy, the AAA was carefully dissected. Infrarenal aorta (IA) just above the AAA was dissected and prepared for cross-clamping. The RAFB's proximal anastomosis

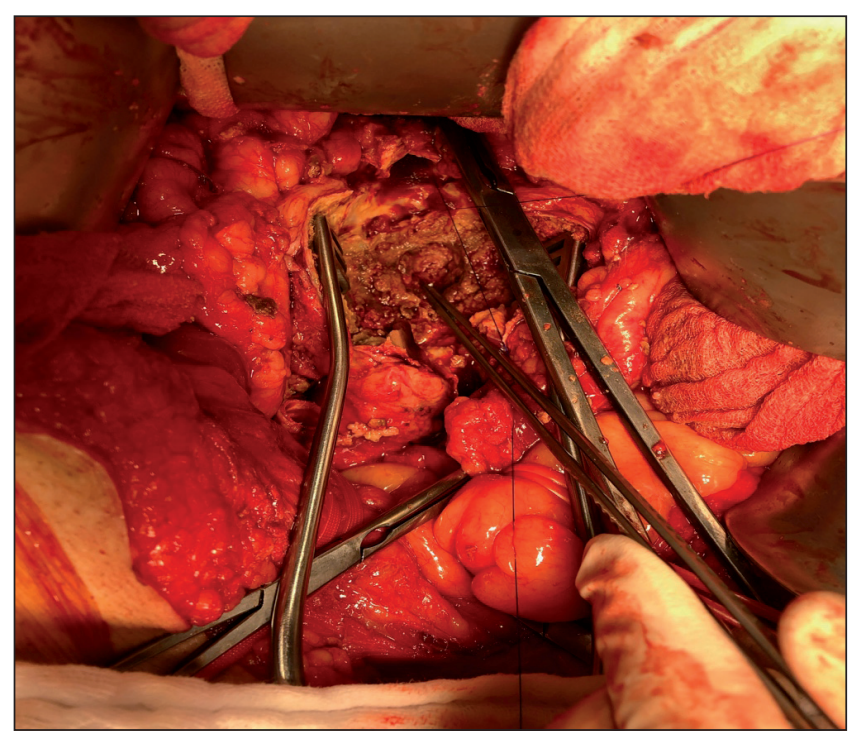

Fig. 2 - Perioperative finding: eroded L4 vertebra form the contained rupture of infrarenal abdominal aneurysm.

emerged from the AAA. The left common iliac artery (LCIA) origin was also partly emerging from the AAA. Under the full heparinization the IA was cross-clamped, the AAA was carefully resected, microbiological cultivation was taken from the AAA sac. The AAA was eroding into the $L 4$ vertebrae. The vertebrae had a smooth surface without signs of infection (Fig. 2). The proximal part of the RFAB was resected; the graft showed no signs of infection. A bifurcated aortic polyester graft (Vascutek ${ }^{\circledR}$ Gelsoft ${ }^{\mathrm{TM}}$ Bifurcate Graft $16 \times 8 \mathrm{~mm}$ ) was used. The proximal end-to-end anastomosis to the IA was performed using Prolen 4/0. The RAFB was implanted to the graft's right arm end-to-end using Prolen 5/0, and the LCIA was implanted to graft's left arm end-to-end using Prolen 5/0 (Fig. 3). The midline laparotomy was closed in a standard manner.

Before the procedure patient was started on a standardized amoxicillin prophylactic antibiotic treatment.
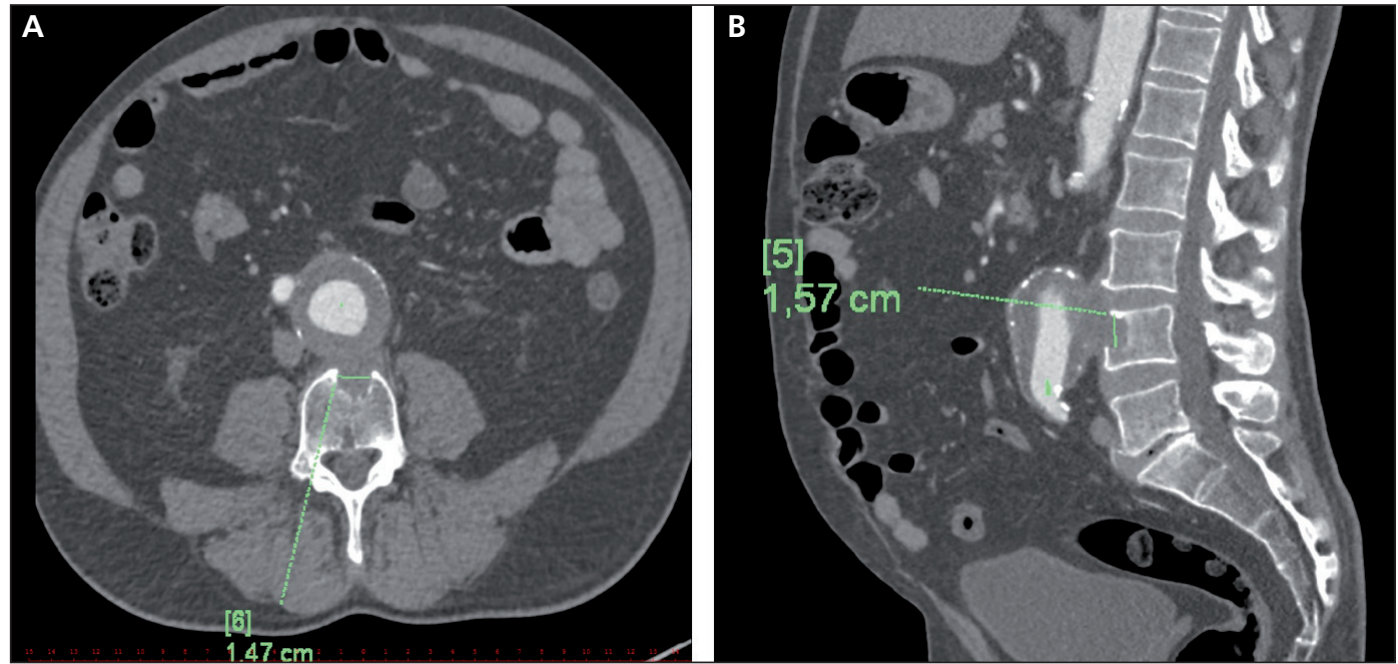

Fig. 1 - Computed angiography of the contained rupture of the $57 \times 63 \mathrm{~mm}$ abdominal aortic aneurysm (AAA) protruding into the L4 vertebra. (A) Cross-section of the AAA with L4 vertebral protrusion. (B) Transverse-section of the AAA with $L 4$ vertebral protrusion. 


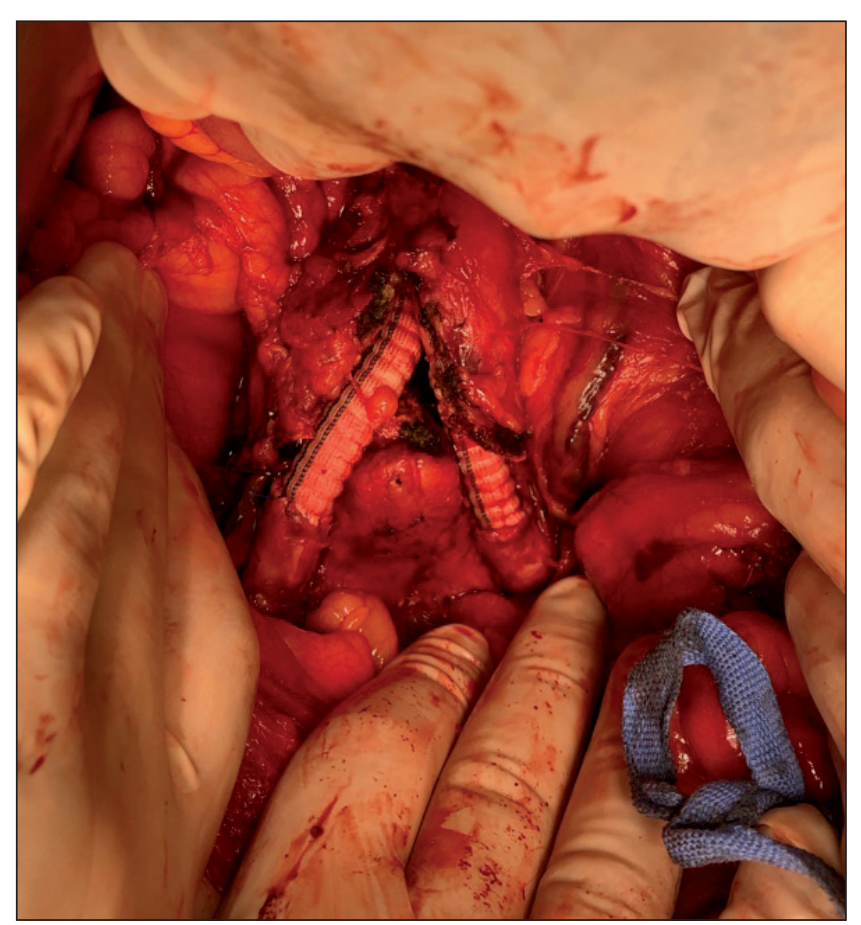

Fig. 3 - Resected abdominal aortic aneurysm using polyester graft with reimplanted right aorto-femoral bypass and left common iliac artery.

On the 5th postoperative day, the patient's inflammatory markers dramatically escalated (CRP: $338 \mathrm{mg} / \mathrm{L}, \mathrm{WBC}$ : $\left.17.7 \times 10^{9} / \mathrm{l}\right)$. Microbiological culture from the AAA sack revealed positive culture of Staphylococcus hominis. A 14-day-long intravenous antibiotic treatment with linezolid was started with good therapeutic effect.

The patient was discharged on the 22nd postoperative day with a $100 \mathrm{mg}$ daily dose of acetylsalicylic acid and further three-week extended antibiotic treatment with oral linezolid.

Currently, we have three months follow up of the patient with no signs of infection in the aortic polyester graft based on ultrasonography.

\section{Discussion}

AAA is usually asymptomatic until a catastrophic rupture. Rupture of an abdominal aortic aneurysm can take place in the following ways; open rupture into the peritoneal cavity, closed rupture into the retroperitoneum, rupture into the surrounding structures, and chronically contained or sealed rupture. ${ }^{3}$ Ruptured AAA is usually presented with shock, lower back pain and pulsatile abdominal mass. ${ }^{3}$

The prevalence of contained ruptured AAA is 3-35\%. ${ }^{4}$ Vertebral erosion is estimated to be present in up to $25 \%$ of these cases. ${ }^{4}$ Progression of the hematoma forcing on to the posterior wall of the AAA may cause vertebral erosion in time. However, the actual mechanism is still unknown. Several hypotheses have been formed regarding the mechanism of vertebral erosion; arterial pulse, hematoma infection, other inflammatory cause. ${ }^{5}$ The latest hypothesis suggests that the inflammatory reaction from the resultant blood products in the retroperitoneal space may result in vertebral body erosive changes. ${ }^{6,7}$

It is essential to differentiate vertebral erosion caused by an aortic aneurysm or infection. Vertebral erosion or protrusion caused purely by aneurysm is smooth. On the contrary, erosion or protrusion caused by an infectious agent is uneven and poorly defined. ${ }^{8} \mathrm{Up}$ to $48 \%$ of patients can have positive microbiological culture from the AAA or blood culture. ${ }^{9}$ Based on this data infection has been implicated as a contributing cause for contained rupture eroding into the vertebrae. This greatly affects the choice of graft selected for the aortal reconstruction as well as postoperative antibiotic protocol.

In our case the proximal part of the RAFB was left in place because; the AAA had smooth surface, during the surgery there were no local signs of infection of the graft, the graft was ingrown into a scar tissue, and the patient had low CRP value. During six-month follow up the patients inflammatory parameters where within normal values (CRP: $1.2 \mathrm{mg} / \mathrm{L}$ ) showing a good effect and sufficient length of the antibiotic treatment. This demonstrates that positive culture from the AAA sac does not necessarily mean a graft infection.

\section{Conclusion}

Low back pain is a widespread medical diagnosis. However, its reason may not always be a primary spine disease. Ruptured AAA should be considered as one of the causes and routinely examined especially in patients with back pain combined with known risk factors such as a smoker, male, age $>65$ years, pulsatile abdominal mass. Chronic contained ruptured AAA with vertebral body erosion is an uncommon manifestation of a ruptured AAA.

\section{Acknowledgement}

The author would like to thank to doc. MUDr. Jiří Froněk, Ph.D., FRCS, and MUDr. Libor Janoušek, Ph.D., FEBS, Transplant Surgery Department, Institute for Clinical and Experimental Medicine, Prague, the Czech Republic for providing their opinion on this case.

\section{Conflict of interest}

The authors declare that there is no conflict of interests regarding the publication of this article.

\section{Funding}

This research received no specific grant from any funding agency in the public, commercial, or not-for-profit sectors.

\section{Informed consent}

Written informed consent was obtained from the patient for publication of this case report and accompanying images. A copy of the written consent is available for review by the Editor-in-Chief of this journal.

\section{References}

1. Choplin RH, Karstaedt N, Wolfman NT. Ruptured abdominal aortic aneurysm simulating pyogenic vertebral spondylitis. Am J Roentgenol 1982;138:748-750. 
2. Desai R, Hong YR, Huo J. Utilization of pain medications and its effect on quality of life, health care utilisation and associated costs in individuals with chronic back pain. J Pain Res 2019;12:557-569.

3. Rajab TK, Beyene MW, Yazdchi F, Menard MT. Aortic Aneurysm Eroding into the Spine. Aorta (Stamford) 2018;6: 68-69.

4. Walker ST, Pipinos II, Johanning JM, Vargo CJ. Contained Rupture of an Abdominal Aortic Aneurysm With Extensive Vertebral Body and Retroperitoneal Space Destruction. J Comput Assist Tomogr 2017;41:839-842.

5. Jiménez Viseu Pinheiro JF, Blanco Blanco JF, Pescador Hernández D, García García FJ. Vertebral destruction due to abdominal aortic aneurysm. Int J Surg Case Rep 2015;6C: 296-299.
6. Aydogan M, Karatoprak O, Mirzanli C, et al. Severe erosion of lumbar vertebral body because of a chronic ruptured abdominal aortic aneurysm. Spine J 2008;8:394-396.

7. Yuksekkaya R, Koner AE, Celikyay F, et al. Multidetector computed tomography angiography findings of chronic-contained thoracoabdominal aortic aneurysm rupture with severe thoracal vertebral body erosion. Case Rep Radiol 2013;2013:596517.

8. Kapoor V, Kanal E, Fukui MB. Vertebral mass resulting from a chronic contained rupture of an abdominal aortic aneurysm repair graft. Am J Neuroradiol 2001;22:1775-1777.

9. Kritpracha B, Premprabha D, Sungsiri J, et al. Endovascular therapy for infected aortic aneurysms. J Vasc Surg 2011:54:1259-1265; discussion 1265. 